\title{
Comparison study of flaxseed, cinnamon and lemon seed essential oils additives on quality and fermentation characteristics of lucerne silage
}

\author{
Maghsoud BESHARATI ${ }^{1}$, Valiollah PALANGI ${ }^{2,3}$, Masomeh NIAZIFAR ${ }^{1}$, Zabihollah NEMATI ${ }^{1}$ \\ Received February 04, 2020; accepted May 5, 2020. \\ Delo je prispelo 04. februarja 2020, sprejeto 05. maja 2020.
}

Comparison study of flaxseed, cinnamon and lemon seed essential oils additives on quality and fermentation characteristics of lucerne silage

Abstract: This experiment was performed to investigate the effects of some essential oils on chemical properties and aerobic stability of lucerne silage. Treatments included lucerne silage without additives (control), lucerne silage with $60 \mathrm{mg}$ cinnamon essential oil $/ \mathrm{kg}$, lucerne silage with $60 \mathrm{mg}$ flaxseed essential oil $/ \mathrm{kg}$, lucerne silage with $60 \mathrm{mg}$ lemon seed essential oil/kg, lucerne silage with $180 \mathrm{mg}$ blend of essential oils (60 mg cinnamon $+60 \mathrm{mg}$ flaxseed $+60 \mathrm{mg}$ lemon seed essential oils/ $\mathrm{kg}$ ). Adding essential oils to lucerne silage reduced silage $\mathrm{pH}$ $(p<0.001)$ compared to control. The highest level of total volatile fatty acids (tVFA) was found when lemon seed essential oil and the lowest level when flaxseed essential oil was used. The lucerne silages treated with essential oils had the highest crude protein contents $(p<0.01)$. Untreated lucerne silage had the highest level of gas production compared to lucerne silage treated with lemon seed and flaxseed essential oils $(p<0.01)$. The essential oil additives increased the aerobic stability of the silage. It can be concluded that the use of essential oil additive in the preparation of high quality lucerne silage, can improves the quality and nutritive value of silages.

Key words: lucerne silage; essential oils; medicinal plants; nutritive value
Primerjava učinkov eteričnih olj lanenih semen, cimeta in limoninega semena na kemično sestavo in fermentacijske značilnosti silaže lucerne

Izvleček: Namen poskusa je bil preučiti učinke nekaterih eteričnih olj na kemijske lastnosti in aerobno stabilnost silaže lucerne. Obravnavanja so obsegala silažo lucerne brez dodatkov (kontrola), silažo lucerne $\mathrm{z}$ dodatkom cimetovega eteričnega olja, silažo lucerne $z$ dodatkom eteričnega olja iz lanenega semena in silažo lucerne $\mathrm{z}$ dodatkom eteričnega olja iz semen limone $\left(60 \mathrm{mg} \mathrm{kg}^{-1}\right)$ in silažo lucerne $\mathrm{z}$ dodatkom $180 \mathrm{mg}$ mešanice eteričnih olj na $\mathrm{kg}$ silaže (60 mg cimetovega $+60 \mathrm{mg}$ lanenega $+60 \mathrm{mg}$ limoninega eteričnega olja na $\mathrm{kg}$ silaže). Dodajanje eteričnihj olj je znižalo $\mathrm{pH}$ silaže $(p<0,001) \mathrm{v}$ primerjavi s kontrolo. Največja vsebnost celokupnih hlapnih maščobnih kislin (tVFA) je bila izmerjena pri dodatku eteričnega olja semen limone in najmanjša pri dodatku eteričnega olja iz lanenega semena. Silaža lucerne, ki je bila obdelana z eteričnimi olji je imela največjo vsebnost surovih beljakovin $(p<0,01)$. Neobdelana silaža lucerne je imela največjo proizvodnjo plina $\mathrm{v}$ primejavo s silažo obdelano z eteričnimi olji iz semen limone in lana $(p<0,01)$. Dodatek eteričnih olj je povečal aerobno stabilnost silaže. Zaključimo lahko, da dodatek eteričnih olj pri pripravi kvalitetne silaže lucerne izboljša njeno kakovost in hranilno vrednost.

Ključne besede: silaža iz lucerne; eterična olja; zdravilne rastline; hranilna vrednostnutritive value

1 University of Tabriz, Ahar Faculty of Agriculture and Natural Resources, Department of Animal Science, Iran

2 Ataturk University, Agricultural Faculty, Department of Animal Science, Erzurum, Turkey

3 Corresponding author, e-mail: dizajparvane@yahoo.com 


\section{INTRODUCTION}

Lucerne is one of the most nutritious forage crops for ruminants. In areas with adverse climates, and in areas where there is not enough time to dry the late harvested lucerne the lucerne is usually ensiled. Lucerne is often difficult to ensile because of its high protein, high buffering capacity and low water-soluble carbohydrate contents (WSC) (Khadem et al., 2009). The use of silage additives could improve the silage quality and its nutritive value. As an option for silage additives the essential oils can be used. Essential oils are natural secondary metabolites that are responsible for providing plants and spices with their characteristic essence and color (Beauchemin, 2008). These non-nutritive and biologically active compounds accumulate in various plant tissues and are extracted by steam-based distillation. Essential oils and their compounds are known to be active against a wide variety of micro-organisms, including Gram-negative bacteria, Gram-positive bacteria and fungi. Although the microbial effect of plant essential oils is recognized, there is limited research about these substances to be used as silage additives. For example, Fraser et al. (2007) observed a reduction in ammonia nitrogen $(\mathrm{NH}-\mathrm{N})$ concentration in culture medium by using cinnamon essential oil. McIntosh et al. (2003) also used a commercial blend of essential oils and observed inhibition of hyperammonia producing bacteria. Moreover, some of former studies demonstrated the potential of essential oils to alter rumen fermentation by reducing the proportion of acetate to propionate and also by inhibition of methanogenesis (Benchear et al., 2007). The aim of this study was to determine the potential use of flaxseed, cinnamon and lemon seed essential oils as silage additives on chemical composition and nutritive value of lucerne silage.

\section{MATERIALS AND METHODS}

\subsection{ESSENTIAL OILS PREPARATION}

Cinnamon, flaxseed and lemon seeds, used in this study, were purchased from local markets in Ahar and Tabriz cities. The samples obtained were cut or crushed into small pieces according to Palangi et al. (2012) pro- cedure, oven-dried at $39^{\circ} \mathrm{C}$ for $48 \mathrm{~h}$ and ground to pass a $1 \mathrm{~mm}$-screen. Essential oils content of each plant was obtained with hydro-distillation of grinded samples using clevenger apparatus (Jahani-Azizabadi et al., 2014). The obtained essential oils were stored in refrigerator $\left(4^{\circ} \mathrm{C}\right)$ until they were used in the experiment.

\subsection{EXPERIMENTAL TREATMENTS AND SILAGE PREPARATION}

The chemical composition of ensiling material is presented in Table 1 . The fourth cut of lucerne was dehydrated for 24 hours. Then it was chopped at $3-5 \mathrm{~cm}$ length and ensiled in laboratory scale mini pvc silos $(3 \pm 0.25 \mathrm{~kg})$ for 60 days. Treatments included lucerne silage without additives (control), lucerne silage with $60 \mathrm{mg}$ cinnamon essential oil/ $/ \mathrm{kg}$ (C60), lucerne silage with $60 \mathrm{mg}$ flaxseed essential oil/kg (F60), lucerne silage with $60 \mathrm{mg}$ lemon seed essential oil/kg (L60), lucerne silage with $180 \mathrm{mg}$ blend of essential oils ( $60 \mathrm{mg}$ cinnamon $+60 \mathrm{mg}$ flaxseed + $60 \mathrm{mg}$ lemon seed essential oils/kg; M60). All additives were dissolved in $120 \mathrm{mg} \mathrm{kg}^{-1}$ aqueous ethanol solution (Chaves et al., 2012) and sprayed onto the chopped forages. The same amount of the aqueous ethanol solution was also added to the control. Three silos for each treatment were made and stored at ambient temperature $\left(28^{\circ} \mathrm{C}\right.$ to $33^{\circ} \mathrm{C}$ ). All silos were opened after 60 days of ensiling and the contents were used for the determination of the silage chemical composition, nutritive value and aerobic stability. Analyses of silage composition and nutritive value were done on the contents of individual silo and averaged for use in the statistical analyses.

\subsection{CHEMICAL COMPOSITION}

After the opening of silages, the $\mathrm{pH}$, dry matter (DM) and soluble carbohydrate (WSC) of the samples were determined. DM content of the silages was determined by oven drying of lucerne samples $\left(65^{\circ} \mathrm{C}\right.$ for $\left.48 \mathrm{~h}\right)$. $\mathrm{DM}$, ash (CA), ether extract (EE) and crude protein (CP) contents were determined by the procedures given by AOAC (2002). The neutral detergent fiber (NDF) and acid detergent fiber (ADF) concentrations were deter-

Table 1: Chemical composition of lucerne before ensiling (\% DM)

\begin{tabular}{llllllll}
\hline Item & \multicolumn{2}{l}{ Chemical composition } & & & & \\
\hline & ADF & NDF & WSC & CA & CP & pH & DM \\
\hline Lucerne & $17 \pm 1.40$ & $24.8 \pm 1.058$ & $3.74 \pm 0.087$ & $11.6 \pm 0.028$ & $19.6 \pm 0.427$ & $6.14 \pm 0.011$ & $22.2 \pm 0.975$ \\
\hline
\end{tabular}

DM, dry matter; CP, crude protein; NDF, neutral detergent fiber; ADF, acid detergent fiber; WCS: water soluble carbohydrates, CA: Crude Ash. 
mined according to Van Soest et al. (1991) procedures without the use of sodium sulphite. NDF was analyzed without amylase and contains the ash. Aqueous extract was prepared from ensiled samples by mixing $20 \mathrm{~g}$ of forage with $180 \mathrm{ml}$ of deionized water and homogenizing this mix for $1 \mathrm{~min}$. Then, silage $\mathrm{pH}$ was determined using a portable $\mathrm{pH}$ meter. Ammonia- $\mathrm{N}\left(\mathrm{NH}_{3}-\mathrm{N}\right)$ concentration of acidified silage extracts were determined using Kjeldahl method. Phenol sulfuric acid method was used to measure WSC contents (Dubios et al., 1956). The distillation method described by Markham (1942) was used to measure total volatile fatty acids (tVFA) in silages. One $\mathrm{ml}$ of $25 \%$ meta-phosphoric acid $(\mathrm{v} / \mathrm{w})$ was added to $5 \mathrm{ml}$ of filtered extract to calculate the volatile fatty acids. For the determination of lactic acid (LA) contents, the method of Borshchevskaya et al. (2016) was used.

\subsection{In vitro GAS PRODUCTION}

Ruminal fluid was collected approximately $2 \mathrm{~h}$ after morning feeding from two fistulated sheep. Gas production was measured by Fedorak and Hrudy (1983) method. Approximately $300 \mathrm{mg}$ of dried and ground $(2 \mathrm{~mm})$ samples were weighed and placed into serum bottles. Rumen fluid buffered with McDougall (1948)'s buffer $(20 \mathrm{ml})$ was pipetted into each serum bottle. The metabolizable energy (ME; $\mathrm{MJ} \mathrm{kg}^{-1} \mathrm{DM}$ ) content of samples was calculated using equation of Getachew et al. (2004) equation. The short chain fatty acid (SCFA) and organic matter digestibility (OMD) for feeds were calculated using equations of Menke et al. (1979) equations. Gas production parameters were calculated using the following mathematical model in the SAS package program according to the model reported by Ørskov and McDonald (1979).

$$
P=a+b\left(1-e^{-c(t)}\right)
$$

where ' $\mathrm{P}$ ' is the disappearance at time ' $\mathrm{t}$ ', 'a' quickly degradable fraction (or washing loss), 'b' denotes slowly degradable fraction and ' $c$ ' is constant rate of degradation of 'b' (Palangi and Macit, 2019).

\subsection{AEROBIC STABILITY}

Aerobic stability of silages represents the time (hours) during which the temperature of silage do not increase more than $2{ }^{\circ} \mathrm{C}$ above ambient temperature (Moran et al., 1996). Aerobic stability was determined on all treatments. About $400 \mathrm{~g}$ of each silage was transferred into separate 11 containers. The containers were implanted with thermocouples to monitor temperature. A double layer of sterile cheesecloth was placed over each container to prevent drying and contamination but allow penetration of air. Silage and ambient temperature were recorded manually every two hours until heating occurred.

\subsection{STATISTICAL ANALYSIS}

Obtained data from this study were subjected to analysis as a completely randomized design by the GLM procedure of SAS (SAS, 2002) and Duncan's multiple range test was used for the comparison of means. Significance was declared at $p<0.01$.

\section{RESULTS AND DISCUSSION}

\subsection{CHEMICAL COMPOSITION}

Effect of essential oil additives on chemical composition of lucerne silage are shown in Table 2. The highest DM contents were observed for F60 and C60 silages which were significantly higher than other silages $(p<0.05)$. This effect could be due the consequence of limited development of specific microorganisms and therefore smaller loss of nutrients (Selwet, 2009). The CP concentrations of M60 and C60 silages were significantly higher than in other silages $(p<0.01)$. Degradation of protein in silage is a consequence of proteolytic microorganisms, such as Clostridia and/or enterobacteria (McDonald et al., 1991). Inhibitory effects of essential oils on growth of some microorganisms such as Clostridia reported in previous studies (Ismaiel and Pierson, 1990). Addition of essential oils to lucerne increased the protein content significantly after $60 \mathrm{~d}$ ensiling. These results were in agreement with findings of Soycan-Önenç et al. (2017) and Chaves et al. (2012). The results of current study show that the addition of M60 did not affect DM contents of silages, what was not in agreement with the findings of Soycan-Önenç et al. (2017).

The $\mathrm{pH}$ of silages supplemented with essential oils was significantly lower than control group $(p<0.01)$. The obtained results of this study were in agreement with the findings of Kung et al. (2000). In addition, the $\mathrm{pH}$ values of all silages were lower than those obtained by Bolsen et al. (1996). In the study by Soycan-Önenç et al. (2017), the $\mathrm{pH}$ values of 4.40 and 4.47 were determined in the silages prepared by addition of oregano and cinnamon essential oil to field peas. Higher $\mathrm{pH}$ values in majority of the treated silages could be the result of the reduced activity of Lactobacillus bacteria, as LA could decrease the $\mathrm{pH}$ of the silage (Kung and Ranjit, 2001). However, in some of 
M. BESHARATI et al.

Table 2: Effect of essential oils on chemical properties of lucerne silage after $60 \mathrm{~d}$ of silage (\% DM)

\begin{tabular}{llllllllllllll}
\hline Treatments $^{1}$ & \multicolumn{2}{l}{ Chemical composition $^{2}$} \\
\cline { 2 - 12 } & DM & NDF & ADF & WSC & tVFA & NH $_{3}$-N & CA & CP & LA & pH & EE \\
\hline Control & $24.44^{\mathrm{c}}$ & $49.07^{\mathrm{a}}$ & $22.67^{\mathrm{b}}$ & $4.09^{\mathrm{b}}$ & $12.63^{\mathrm{b}}$ & $84.93^{\mathrm{a}}$ & $11.40^{\mathrm{c}}$ & $11.62^{\mathrm{d}}$ & $69.38^{\mathrm{d}}$ & $4.65^{\mathrm{a}}$ & $4.27^{\mathrm{c}}$ \\
C60 & $25.68^{\mathrm{b}}$ & $42.43^{\mathrm{bc}}$ & $25.67^{\mathrm{a}}$ & $4.78^{\mathrm{a}}$ & $11.65^{\mathrm{c}}$ & $79.80^{\mathrm{b}}$ & $11.66^{\mathrm{b}}$ & $12.29^{\mathrm{b}}$ & $80.29^{\mathrm{a}}$ & $3.66^{\mathrm{b}}$ & $3.94^{\mathrm{c}}$ \\
F60 & $26.82^{\mathrm{a}}$ & $43.17^{\mathrm{b}}$ & $15.34^{\mathrm{d}}$ & $4.05^{\mathrm{b}}$ & $10.36^{\mathrm{d}}$ & $83.53^{\mathrm{a}}$ & $10.80^{\mathrm{d}}$ & $12.22^{\mathrm{c}}$ & $71.22^{\mathrm{c}}$ & $3.73^{\mathrm{b}}$ & $4.07^{\mathrm{c}}$ \\
L60 & $24.50^{\mathrm{c}}$ & $48.03^{\mathrm{a}}$ & $19.34^{\mathrm{c}}$ & $4.63^{\mathrm{a}}$ & $14.90^{\mathrm{a}}$ & $85.16^{\mathrm{a}}$ & $12.31^{\mathrm{a}}$ & $12.37^{\mathrm{b}}$ & $76.23^{\mathrm{b}}$ & $3.61^{\mathrm{b}}$ & $4.73^{\mathrm{a}}$ \\
M60 & $24.23^{\mathrm{c}}$ & $39.60^{\mathrm{c}}$ & $18.67^{\mathrm{c}}$ & $4.24^{\mathrm{b}}$ & $12.77^{\mathrm{b}}$ & $83.53^{\mathrm{a}}$ & $11.70^{\mathrm{b}}$ & $12.54^{\mathrm{a}}$ & $70.82^{\mathrm{c}}$ & $3.79^{\mathrm{b}}$ & $4.53^{\mathrm{ab}}$ \\
SEM & 0.308 & 1.039 & 0.615 & 0.066 & 0.049 & 0.660 & 0.518 & 0.043 & 0.244 & 0.055 & 0.123 \\
p-value & 0.0005 & 0.0003 & $<.0001$ & $<.0001$ & $<.0001$ & 0.0013 & $<.0001$ & $<.0001$ & $<.0001$ & $<.0001$ & 0.0055 \\
\hline
\end{tabular}

Treatment ${ }^{1}$-control: Lucerne silage without additives, C60: lucerne silage with $60 \mathrm{mg}$ cinnamon essential oil $\mathrm{kg}^{-1}$, F60: lucerne silage with $60 \mathrm{mg}$ flaxseed essential oil kg $\mathrm{kg}^{-1}$, 660: lucerne silage with $60 \mathrm{mg}$ lemon seed essential oil kg ${ }^{-1}$, M60: lucerne silage with $180 \mathrm{mg}$ blend of essential oils (60 mg cinnamon essential oil + $60 \mathrm{mg}$ flaxseed essential oil $+60 \mathrm{mg}$ lemon seed essential oil $\left.\mathrm{kg}^{-1}\right)$.

Chemical composition²: DM, dry matter; $\mathrm{CP}$, crude protein; EE, ether extract; CA, crude ash; NDF, neutral detergent fiber; $\mathrm{ADF}$, acid detergent fiber; $\mathrm{NH}_{3}-\mathrm{N}$ : ammonia nitrogen (\% of total nitrogen), tVFA: total volatile fatty acid (mmol), LA: lactic acid. WSC: water soluble carbohydrate.

Means within same column with different superscripts differ $(p<0.05)$.

the previous studies, essential oils had no inhibitory effect on lactic acid producing bacteria (Kung et al., 2008).

$\mathrm{NH}_{3}-\mathrm{N}$ content significantly decreased in C60 silage $(p<0.01$; Table 2). The treatments F60, L60 and M60 had no effect on $\mathrm{NH}_{3}-\mathrm{N}$ concentration, which is in agreement with the findings of Kung et al. (2008). In the study of Hodjatpanah et al. (2016), essential oils of cinnamon added to ensiling material in amounts of 120 and $240 \mathrm{mg} \mathrm{kg}^{-1}$, had no effect on $\mathrm{NH}_{3}-\mathrm{N}$ in corn silage, whereas essential oils of oregano and thyme in same amounts and peppermint essential oil in amount of $120 \mathrm{mg} \mathrm{kg}^{-1}$ level decreased $\mathrm{NH}_{3}-\mathrm{N}$ content.

The amounts of tVFAs determined in silages in this experiment was different by the addition of essential oil (Table 2). The highest amount of tVFA was found in L60 and the lowest in F60. Essential oils obtained from cinnamon and flaxseed decreased tVFA concentration in comparison to control $(p<0.01)$.

It is possible that the decrease of NDF and ADF contents is affected by pH. Soycan-Önenç et al. (2017) determined that LA content decreased in field pea silages prepared with the addition of oregano, cinnamon, and oregano+cinnamon essential oils. However, in this study it was determined that there was an increase in LA contents. While F60 and M60 reveal a decreasing effect on LA amount through inhibiting beneficial microorganisms, C60 caused increase in lactic acid amount by promoting beneficial microorganisms activity.

\subsection{GAS PRODUCTION}

Relative to the control, total produced gas from L60 and F60 decreased $(p<0.01)$ and M60 produced more gas $(p<0.01)$ after $120 \mathrm{~h}$ of incubation (Table 3$)$. The chemical composition of silage can influence on the rumen microbial fermentation patterns (Navarro-Villa et al., 2013). Furthermore, some of essential oils have a good potential to alter rumen microbial fermentation and specially reducing rumen methanogenesis (JahaniAzizabadi et al., 2014) and ammonia producing bacteria in the rumen (McIntosh et al., 2003).

Effects of essential oils on rumen microbial populations are dose-dependent (Macheboeuf et al., 2008). Effects of essential oils on NH3-N concentrations were only noticed during the first $120 \mathrm{~h}$ of incubation. At $120 \mathrm{~h}$, treatments M60, F60 and L60 had higher $(p<0.01)$ ammonia concentration than the control (Table 4$)$. The cumulative curve of gas production parameters in different lucerne silage treatments is shown in Figure 1.

At the end of incubation, the highest volume of gas produced was obtained with M60 with $148.54 \mathrm{ml} \mathrm{g}^{-1} \mathrm{DM}$ and the lowest was for treatment F60 with $123.43 \mathrm{ml} \mathrm{g}^{-1}$ $\mathrm{DM}$. The results of this experiment are in agreement with the findings of Hodjatpanah et al. (2016) and Chavez et al. (2012). Aminipour et al. (2017) used thyme essential oils as an additive to alter the fermentation characteristics of lucerne silage in ruminants and showed that thyme essential oil reduced the amount of gas produced in comparison with control silage. Fraser et al. (2007) used cinnamon essential oil which reduced the amount of gas produced after $24 \mathrm{~h}$ of incubation. Thestudy of Busquet et al. (2005) showed that the use of garlic essential oil reduced the amount of gas production after 17 hours of incubation and that the increasing levels of garlic essential oil levels decreased the in vitro gas production.

The mean gas produced from the potential degradable (b) was significantly different between the experi- 
Comparison study of flaxseed, cinnamon and lemon seed essential oils additives on quality and fermentation characteristics of lucerne silage

Table 3: The effect of different essential oils on gas production of lucerne silage ( $\left.\mathrm{ml} \mathrm{g}^{-1} \mathrm{DM}\right)$

\begin{tabular}{llllllllllllll}
\hline Treatments $^{1}$ & \multicolumn{2}{l}{ Incubation times $(\mathrm{h})$} \\
\cline { 2 - 13 } & 2 & 4 & 6 & 8 & 12 & 16 & 24 & 36 & 48 & 72 & 96 & 120 \\
\hline Control & $17.61^{\mathrm{b}}$ & $32.40^{\mathrm{b}}$ & $40.06^{\mathrm{b}}$ & $51.72^{\mathrm{b}}$ & $65.18^{\mathrm{b}}$ & $82.28^{\mathrm{b}}$ & $103.98^{\mathrm{b}}$ & $111.98^{\mathrm{b}}$ & $123.10^{\mathrm{b}}$ & $130.90^{\mathrm{b}}$ & $134.42^{\mathrm{b}}$ & $135.52^{\mathrm{b}}$ \\
C60 & $15.51^{\mathrm{bc}}$ & $30.83^{\mathrm{bc}}$ & $38.50^{\mathrm{bc}}$ & $45.83^{\mathrm{c}}$ & $55.94^{\mathrm{c}}$ & $70.79^{\mathrm{c}}$ & $89.02^{\mathrm{c}}$ & $104.75^{\mathrm{c}}$ & $115.54^{\mathrm{c}}$ & $122.13^{\mathrm{c}}$ & $126.47^{\mathrm{c}}$ & $128.70^{\mathrm{c}}$ \\
F60 & $14.18^{\mathrm{c}}$ & $27.50^{\mathrm{c}}$ & $35.03^{\mathrm{c}}$ & $45.22^{\mathrm{c}}$ & $56.01^{\mathrm{c}}$ & $69.19^{\mathrm{c}}$ & $88.70^{\mathrm{c}}$ & $99.56^{\mathrm{c}}$ & $110.29^{\mathrm{c}}$ & $118.94^{\mathrm{c}}$ & $121.80^{\mathrm{c}}$ & $123.43^{\mathrm{c}}$ \\
L60 & $13.59^{\mathrm{c}}$ & $27.03^{\mathrm{c}}$ & $37.50^{\mathrm{bc}}$ & $50.50^{\mathrm{b}}$ & $60.74^{\mathrm{bc}}$ & $73.11^{\mathrm{c}}$ & $89.16^{\mathrm{c}}$ & $102.22^{\mathrm{c}}$ & $112.14^{\mathrm{c}}$ & $117.74^{\mathrm{c}}$ & $122.87^{\mathrm{c}}$ & $124.97^{\mathrm{c}}$ \\
M60 & $20.24^{\mathrm{a}}$ & $40.02^{\mathrm{a}}$ & $50.01^{\mathrm{a}}$ & $62.48^{\mathrm{a}}$ & $76.33^{\mathrm{a}}$ & $91.63^{\mathrm{a}}$ & $110.93^{\mathrm{a}}$ & $126.12^{\mathrm{a}}$ & $137.12^{\mathrm{a}}$ & $143.79^{\mathrm{a}}$ & $147.74^{\mathrm{a}}$ & $148.54^{\mathrm{a}}$ \\
SEM & 0.802 & 1.392 & 1.344 & 1.490 & 1.561 & 1.845 & 2.101 & 1.981 & 2.445 & 2.434 & 2.397 & 2.411 \\
\hline
\end{tabular}

Treatment ${ }^{1}$-control: Lucerne silage without additives, C60: lucerne silage with $60 \mathrm{mg}$ cinnamon essential oil/kg, F60: lucerne silage with $60 \mathrm{mg}$ flaxseed essential oil $\mathrm{kg}^{-1}$, L60: lucerne silage with $60 \mathrm{mg}$ lemon seed essential oil kg${ }^{-1}, \mathrm{M} 60$ : lucerne silage with $180 \mathrm{mg}$ blend of essential oils (60 mg cinnamon essential oil $+60 \mathrm{mg}$ flaxseed essential oil $+60 \mathrm{mg}$ lemon seed essential oil $\left.\mathrm{kg}^{-1}\right)$.

Means within same column with different superscripts differ $(p<0.05)$.

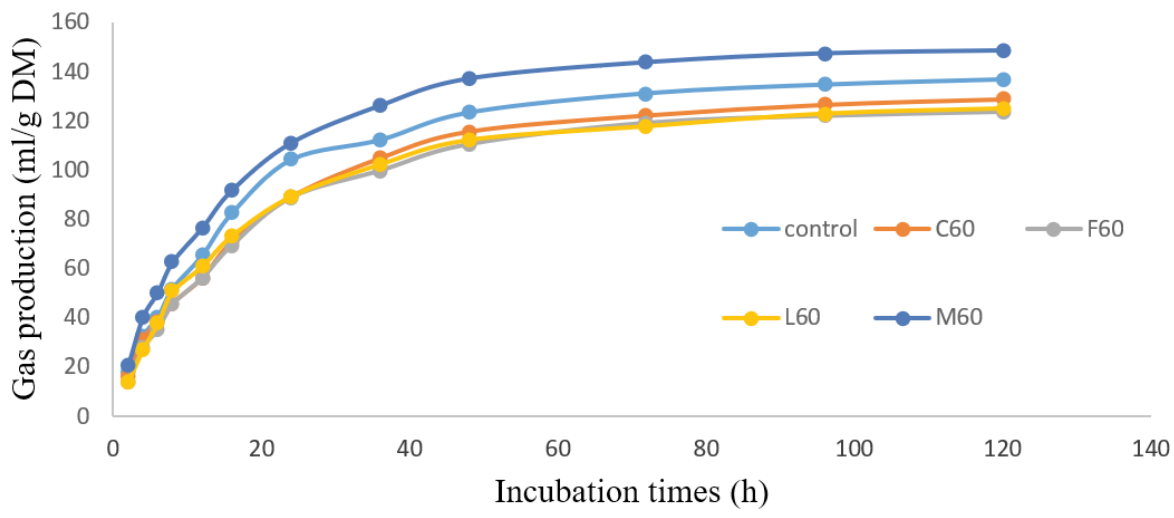

Figure 1: The effect of essential oils on gas production at different incubation times of lucerne silage

mental treatments. The treatment M60 had the highest $b$ and $c$ amounts among the treatments $(p<0.01)$.

Lucerne silage prepared with addition of essential oils lucerne had a significant effect on tVFA and $\mathrm{NH}_{3}$ N. Treatments M60 and L60 had the highest tVFA and $\mathrm{NH}_{3}-\mathrm{N}$ among treatments, respectively. Treatments F60 and $\mathrm{C} 60$ increased the amounts of tVFA and $\mathrm{NH}_{3}-\mathrm{N}$ in comparison with control, respectively. Hart et al. (2008) using medium containing a set of rumen microorganisms showed that limonene, thymol, vanillin, guaiacol and oregano extract reduced rumen $\mathrm{NH}_{3}-\mathrm{N}$ concentration. Brochers (1965) showed that the addition of thymol to rumen fluid resulted in the accumulation of amino acids and a decrease in $\mathrm{NH}_{3}-\mathrm{N}$ concentration. He suggested that the thymol prevents the deamination of amino acids by rumen bacteria. It seems that since the plant essential oils have inhibitory effects on proteolysis and deamination, their inhibitory effects on proteolytic activities may reduce the degradation of the silage protein and consequently decrease the ammonia nitrogen content. The re- duction in $\mathrm{NH}_{3}-\mathrm{N}$ concentration has been attributed to the antimicrobial activity of essential oils. This property limits the fermentation process and reduces the breakdown of protein into ammonia. It has also been suggested that effective compounds in essential oils are able to bind to proteins, which reduces nitrogen loss.

\subsection{AEROBIC STABILITY}

All silages treated with essential oils improved the aerobic stability compared with control, of which control obtained $77 \mathrm{~h}$, while M60, C60, L60, and F60 obtained $112,>99.33,>96.66,>92 \mathrm{~h}$, respectively. Higher aerobic stability of treated silages was in agreement with the findings of Chaves et al. (2012). In their experiment, silages treated with oregano or cinnamon leaf essential oils at $120 \mathrm{mg} \mathrm{kg}^{-1}$ remained stable for two weeks. Exposure to air in silos may result in silage deterioration. The increase in temperature is the result of the metabolism of organic 
Table 4: The effect of experimental treatments on gas production parameters of lucerne silage

\begin{tabular}{|c|c|c|c|c|c|c|c|c|c|c|}
\hline \multirow[t]{2}{*}{ Treatments ${ }^{1}$} & \multicolumn{10}{|l|}{ Items $^{2}$} \\
\hline & $\mathrm{pH}$ & $\mathrm{NE}_{\mathrm{L}}$ & SCFA & $\mathrm{ME}$ & OMD & DOMD & tVFA & $\mathrm{NH}_{3}-\mathrm{N}$ & $b$ & $c$ \\
\hline Control & $6.60^{\mathrm{ab}}$ & $1.26^{\mathrm{a}}$ & $0.152^{\mathrm{a}}$ & $3.22^{\mathrm{a}}$ & $27.23^{\mathrm{a}}$ & $24.01^{\mathrm{ab}}$ & $8.62^{\mathrm{b}}$ & $47.22^{\mathrm{c}}$ & $133.74^{\mathrm{b}}$ & $0.0592^{b}$ \\
\hline C60 & $6.63^{\mathrm{ab}}$ & $1.17^{\mathrm{bc}}$ & $0.128^{b c}$ & $3.08^{\mathrm{bc}}$ & $26.55^{\mathrm{ab}}$ & $23.46^{b c}$ & $7.14^{\mathrm{c}}$ & $29.36^{\mathrm{d}}$ & $126.78^{b c}$ & $0.0526^{\mathrm{d}}$ \\
\hline F60 & $6.60^{\mathrm{ab}}$ & $1.20^{\mathrm{ab}}$ & $0.137^{\mathrm{ab}}$ & $3.14^{\mathrm{ab}}$ & $26.90^{\mathrm{a}}$ & $24.26^{\mathrm{a}}$ & $3.00^{\mathrm{d}}$ & $47.91^{\mathrm{c}}$ & $121.62^{c}$ & $0.0539^{\mathrm{d} c}$ \\
\hline L60 & $6.50^{\mathrm{b}}$ & $1.10^{c}$ & $0.1142^{c}$ & $3.00^{c}$ & $26.05^{b}$ & $23.01^{\mathrm{c}}$ & $3.26^{\mathrm{d}}$ & $51.10^{\mathrm{a}}$ & $121.92^{c}$ & $0.0579^{\mathrm{bc}}$ \\
\hline M60 & $6.65^{\mathrm{a}}$ & $1.20^{\mathrm{ab}}$ & $0.1360^{\mathrm{ab}}$ & $3.13^{\mathrm{ab}}$ & $26.92^{\mathrm{a}}$ & $23.74^{\mathrm{ab}}$ & $12.92^{\mathrm{a}}$ & $49.71^{\mathrm{b}}$ & $145.34^{\mathrm{a}}$ & $0.0645^{\mathrm{a}}$ \\
\hline SEM & 0.042 & 0.026 & 0.006 & 0.036 & 0.240 & 0.202 & 0.438 & 0.467 & 2.488 & 0.002 \\
\hline p-value & 0.1641 & 0.0041 & 0.0041 & 0.0047 & 0.0244 & 0.0016 & $<.0001$ & $<.0001$ & $<.0001$ & 0.0006 \\
\hline
\end{tabular}

Treatment ${ }^{1}$-control: Lucerne silage without additives, C60: lucerne silage with $60 \mathrm{mg}$ cinnamon essential oil $\mathrm{kg}^{-1}$, F60: lucerne silage with $60 \mathrm{mg}$ flaxseed essential oil $\mathrm{kg}^{-1}$, L60: lucerne silage with $60 \mathrm{mg}$ lemon seed essential oil kg-1, M60: lucerne silage with $180 \mathrm{mg}$ blend of essential oils (60 mg cinnamon essential oil + $60 \mathrm{mg}$ flaxseed essential oil $+60 \mathrm{mg}$ lemon seed essential oil $\left.\mathrm{kg}^{-1}\right)$.

ME: metabolizable energy (MJ/Kg DM); SCFA: short chain fatty acid ( $\left.m m o l ~ 0.2 \mathrm{~g}^{-1} \mathrm{DM}\right)$; DOMD: digestible organic matter in dry matter (\%); $\mathrm{NE}_{\mathrm{L}}$ : net energy lactation (MJ kg-1 DM); tVFA: total volatile fatty acids ( $\left.\mathrm{mmol} \mathrm{l}^{-1}\right) ; \mathrm{NH}_{3}-\mathrm{N}$ : ammonia nitrogen ( $\left.\mathrm{mg} \mathrm{l}^{-1}\right)$; OMD: organic matter digestibility (\%); b: gas production of the potentially degradable (insoluble); c: fraction after $24 \mathrm{~h}$ incubation $\left(\mathrm{ml} 200 \mathrm{mg}^{-1} \mathrm{DM}\right)$.

Means within same column with different superscripts differ $(p<0.05)$.

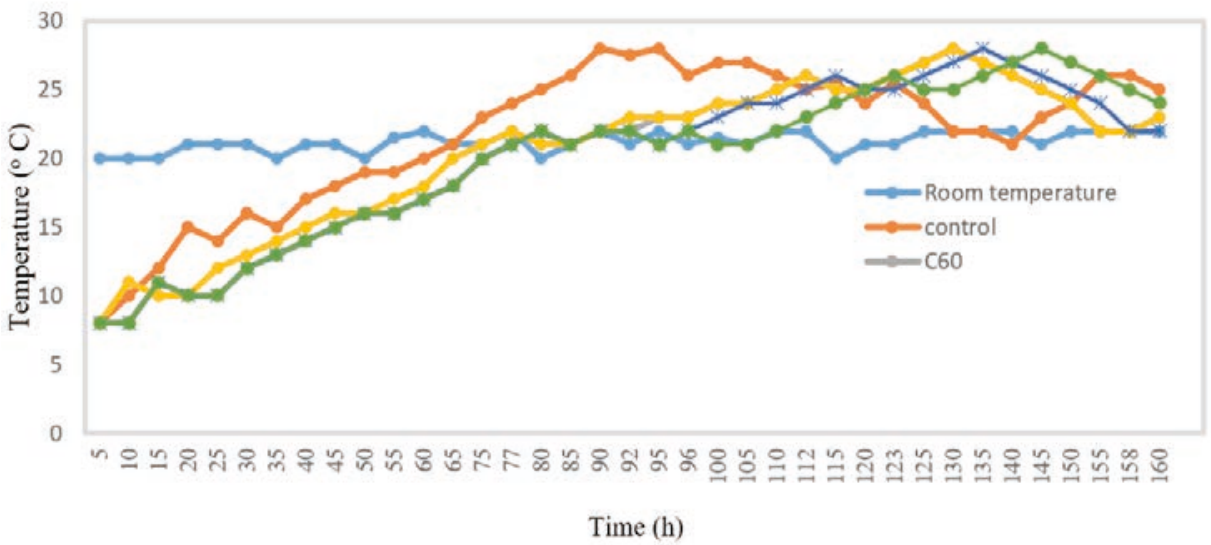

Figure 2: The effect of adding essential oils on aerobic stability of alfalfa silage

acids and nutrients by aerobic microorganisms. Changes in temperature can be an indicator of the development of aerobic deterioration of silages. In study of Chaves et al. (2012) the silages supplemented with $120 \mathrm{mg}$ of pineapple or thyme essential oil kg-1 DM, remained stable for two weeks. Some secondary plant metabolites have been shown to inhibit the growth of some yeast species associated with aerobic degradation (Soycan-Önenç et al., 2017). In the study of Chaves et al. (2012), addition of 3 different herbal essential oils (cinnamon, oregano and sweet orange at $120 \mathrm{mg} \mathrm{kg}^{-1} \mathrm{DM}$ ) to barley silage increased aerobic stability compared to the control treatment. Hodjatpanah et al. (2016) added different herbal essential oils (oregano, thyme, cumin and cinnamon) to corn silage which improved aerobic stability of silages. The improved stability was attributed to inhibitory ef- fects of essential oils on the growth and activities of yeast species that initiate deterioration of silages. Kung et al. (2000) reported that propionic acid, suberic acid, benzoic acid, acetic acid and ammonia are among the substances that increase the aerobic stability of silage.

\section{CONCLUSION}

In conclusion, some essential oils, which were used as silage additives in this study, had positive effects on quality of lucerne silage. The M60 protected silage protein against deleterious deamination by decreasing $\mathrm{pH}$ of the silage which increased the aerobic stability of the silage. Moreover, results regarding gas production demonstrated the potential of lemon seed and flaxseed essen- 
tial oils to promote fermentation efficiency through reduction of gas production. Based on the obtained results, it can be concluded that the use of essential oil as silage additives Lucerne have a potential in improving its nutritional value as well as silage aerobic stability.

\section{REFRENCES}

Amini Pour, H., Naserian, A., Vakiliand, A.R. and Tahmasbi, A.M. (2017). Effect of essential plant oil used as an additive to alter silage fermentation in ruminant by in vitro. Biosciences Biotechnology Research Asia, 14(1), 145-152. https://doi.org/10.13005/bbra/2429

Association of Offical Analytic Chemists (AOAC) (2002). Official method of Analytic. Vol. 1. 17 thed. AOAC, Arilington VA. P: 120-155.

Beauchemin, K.A. (2008). A review of plant derived essential oils in ruminant nutrition and production. Animal Feed Science and Technology, 145, 209-228. https://doi. org/10.1016/j.anifeedsci.2007.04.014

Benchaar, C., Chaves, A.V., Fraser, G.R., Wang, Y., Beauchemin, K.A. and McAllister, T.A. (2007). Effects of essential oils and their components on in vitro rumen microbial fermentation. Canadian Journal of Animal Science, 87, 413-419. https://doi.org/10.4141/CJAS07012

Bolsen, K.K., Bonilla, D.R., Huck, G.L., Young, M.A. and HartThakur, R.A. (1996). Effect of propionic acid bacterial inoculant on fermentation and aerobic stability of whole-plant corn silage. In: Report of Progress of Kansas State University Agricultural Experiment Station. Kansas State University, Manhattan, P: 78-81. https://doi.org/10.4148/23785977.2008

Borshchevskaya, L.N., Gordeeva, T.L., Kalinina, N. and Sineokii, S.P. (2016). Spectrophotometric determination of lactic acid. Journal of Analytical Chemistry, 71(8), 755-758. https://doi.org/10.1134/S1061934816080037

Brochers, R. (1965). Proteolytic activity of rumen fluid in $v i$ tro. Journal of Animal Science, 24, 1033-1038. https://doi. org/10.2527/jas1965.2441033x

Busquet, M., Calsamiglia, S., Ferret, A. and Kamel, C. (2005). Screening for the effects of natural plant extracts and secondary plant metabolites on rumen microbial fermentation in continuous culture. Animal Feed Science and Technology, 123, 597-613. https://doi.org/10.1016/j.anifeedsci.2005.03.008

Chaves, A.V., Baah, J., Wang, Y., McAllistera, T.A. and Benchaar, C. (2012). Effects of cinnamon leaf, oregano and sweet orange essential oils on fermentation and aerobic stability of barley silage. Journal of the Science of Food and Agriculture, 92(4), 906-915. https://doi.org/10.1002/jsfa.4669

Cheng, Y., Chen, C. and Peng, P. (2001). Effects of Different Additives on Silage Quality of Napier grass. Proceedings of the 19th International Grassland Congress, San Pedro, P: 233238.

Dubios, A., Giles, M.K.A., Hamilton, J.K., Ronerts, P.A. and Smith, F. (1956). Colorimetric method for determination of sugars and related substances. Journal of Analytical Chemistry, 28, 350-356. https://doi.org/10.1021/ac60111a017

Fedorah, P.M. and Hrudey, S.E. (1983). A simple apparatus for measuring gas production by methanogenic cultures serum bottles. Environmental Science \& Technology Letters, 4, 425435. https://doi.org/10.1080/09593338309384228

Fraser, G.R., Chaves, A.V., Wang, Y., McAllister, T.A., Beauchemin, K.A. and Benchaar, C. (2007). Assessment of the effects of cinnamon leaf oil on rumen microbial fermentation using two continuous culture systems. Journal of Dairy Science, 90, 2315-2328. https://doi.org/10.3168/jds.2006-688

Fraser, G.R., Chaves, A.V., Wang, Y., McAllister, T.A., Beauchemin, K.A. and Benchaar, C. (2007). Assessment of the effects of cinnamon leaf oil on rumen microbial fermentation using two continuous culture systems. Journal of Dairy Science, 90, 2315-2328. https://doi.org/10.3168/jds.2006-688

Getachew, G., Robinson, P.H., DePeters, E.J. and Taylor, S.J. (2004). Relationships between chemical composition, dry matter degradation and in vitro gas production of several ruminants feed. Animal Feed Science and Technology, 111, 57-71. https://doi.org/10.1016/S0377-8401(03)00217-7

Hart, K.J., Yáñez-Ruiz, D.R., Duval, S.M., McEwan, N.R. and Newbold, C.J. (2008). Plant extracts to manipulate rumen fermentation. Animal Feed Science and Technology, 147, 8-35. https://doi.org/10.1016/j.anifeedsci.2007.09.007

Hodjatpanah-Montazeri, M., Danesh Mesgaran, M. and Vakili, A. (2016). Effect of essential oils of various plants as microbial modifier to alter corn silage fermentation and in vitro methane production. Iranian Journal of Applied Animal Science, 6(2), 269-276 (in Persian).

Ismaiel, A. and Pierson, M.D. (1990). Inhibition of growth and germination of C. botulinum 33A, 40B, and 1623E by essential oil of species. Journal of Food Science, 55, 1676-1678. https://doi.org/10.1111/j.1365-2621.1990.tb03598.x

Jahani-Azizabadi, H., Danesh-Mesgaran, M., Vakili, A.R. and Rezayazdi, K. (2014). Effect of some plant essential oils on in vitro ruminal methane production and on fermentation characteristics of a mid-forage diet. Journal of Agricultural Science and Technology, 16, 1543-1554.

Khadem, A.A., Sharifi, M., Afzalzadeh A. and Rezaeian, M. (2009). Effects of diets containing alfalfa hay or barley flour mixed alfalfa silage on feeding behavior, productivity, rumen fermentation and blood metabolites in lactating cows. Journal of Animal Science, 80, 403-410. https://doi. org/10.1111/j.1740-0929.2009.00653.x

Kung, L.J. and Ranjit, N.K. (2001). The effect of Lactobacillus buchneri and other additives on the fermentation and aerobic stability of barley silage. Journal of Dairy Science, 84, 11491155. https://doi.org/10.3168/jds.S0022-0302(01)74575-4

Kung, L.J., Williams, P., Schmidt, R.J. and Hu, W. (2008). A blend of essential plant oils used as an additive to alter silage fermentation or used as a feed additive for lactating dairy cows. Journal of Dairy Science, 91, 4793-4800. https:// doi.org/10.3168/jds.2008-1402

Kung, L.J.R., Robinson, J.R., Ranjit, N.K., Chen, J.H., Golt, C.M. and Pesek, J.D. (2000). Microbial population, fermentation end-products, and aerobic stability of corn silage treated with ammonia or a propionic acid-based preservative. Jour- 
nal of Dairy Science, 83, 1479-1486. https://doi.org/10.3168/ jds.S0022-0302(00)75020-X

Macheboeuf, D., Morgavi, D.P., Papon, Y., Mousset, J.L. and Arturo-Schaan, M. (2008). Dose-response effects of essential oils on in vitro fermentation activity of the rumen microbial population. Animal Feed Science and Technology, 145, 335-350. https://doi.org/10.1016/j.anifeedsci.2007.05.044

Markham, R. (1942). A steam distillation apparatus suitable for micro-Kjeldahl analysis. Biochemical Journal, 36, 790. https://doi.org/10.1042/bj0360790

McDonald, P., Henderson, A.R. and Heron, S.J.E. (1991). The Biochemistry of Silage. Chalcombe Publications, Marlow, UK, P: 184-236.

McDougall, E.I. (1948). The composition and output of sheep in saliva. Biochemical Journal, 43, 99-109. https://doi. org/10.1042/bj0430099

McIntosh, F.M., Williams, P., Losa, R., Wallace, R.J., Beever, D.A. and Newbold, C.J. (2003). Effects of essential oils on ruminal microorganisms and their protein metabolism. Applied Environmental Microbiology, 69, 5011-5014. https://doi.org/10.1128/AEM.69.8.5011-5014.2003

Menke, K.H., Raab, L., Salewski, A., Steingass, H., Fritz, D. and Schneider, W. (1979). The estimation of the digestibility and metabolisable energy content of ruminant feeding stuffs from the gas production when they are incubated with rumen liquor in vitro. Journal of Agriculture and Food Sciences, 93, 217-222. https://doi.org/10.1017/S0021859600086305

Moran, J.P., Weinberg, Z.G., Ashbell, G., Hen, Y. and Owen, T.R. (1996). A comparison of two methods for the evalua- tion of the aerobic stability of whole crop wheat silage. Proc. 11st Int. Silage Conf. Aberystwyth, UK, P. 162-163.

Navarro-Villa, A., O’Brien, M., López, S., Boland, T.M. and O'Kiely, P. (2013). In vitro rumen methane output of grasses and grass silages differing in fermentation characteristics using the gas-production technique (GPT). Grass and Forage Science, 68(2), 228-244. https://doi.org/10.1111/j.13652494.2012.00894.x

Palangi, V., Khoshvaghti, H., Sharafi, Y. and Eivazi, P. (2012). Determination of nutritive value of Sallow and Service leaves using nylon bags and gas production techniques. Indian Journal of Animal Research. 40, 361-365.

Palangi, V. and Macit, M. (2019). In situ crude protein and dry matter ruminal degradability of heat-treated barley. Revue de Médecine Vétérinaire. 170, 123-128.

Statistical Analysis Systems (SAS) (2002). Sas User's Guide: Statistics. Statistical Analysis Systems Institute Inc, Cary, NC.

Selwet, M. (2009). Effect of propionic and formic acid mixtures on the fermentation, fungi development and aerobic stability of maize silage. Polish Journal of Agronomy, 1, 37-42.

Soycan-Önenç, S., Coşkuntuna, L., Koç, F., Özdüven, M.L. and Gümüş, T. (2017). Effects of essential oils of oregano and cinnamon on fermentation quality and in vitro metabolic energy of field pea silages. Animal Production Science, 58(2), 39-44.

Van Soest, P.J., Robertson, J.B. and Lewis, B.A. (1991). Methods for dietary fiber, neutral detergent fiber, and nonstarch polysaccharides in relation to animal nutrition. Journal of Dairy Science, 74, 3583. https://doi.org/10.3168/jds.S00220302(91)78551-2 